\title{
Textos de Identidad Multimodales en el Aula de Inglés como Lengua Extranjera: Una Herramienta para Desarrollo de Habilidades Cognitivas y Académicas de Competencia Linguística
}

\section{María Dolores García-Pastor ${ }^{\mathrm{a}}$}

${ }^{a}$ Facultat de Magisteri, Universitat de València, maria.d.garcia@uv.es ${ }^{1}$

\begin{abstract}
The present action-research project in progress deals with the production and evaluation of "identity texts" (Cummins \& Early, 2011) from EFL students in the context of a specific subject within the major of English Teacher in Primary Education at the Faculty of Education of the Universitat de València. This project is part of a larger "Innovation in education" project, whose main objective is to promote the use of identity texts as the key strategy of the "teaching for linguistic transfer" approach (Cummins, 2005b). Identity texts foster learners' cognitive and academic transfer from their first language (L1) to their second or foreign language (L2/FL), and offer students an opportunity to explore their "selves" through the use of written, oral, visual, musical and theatrical texts or a combination of all these into a multimodal whole (i.e., videos, digital stories, etc.). In the present project, learners are encouraged to explore their identities as EFL learners with the aim of a) raising their awareness of who they are as language learners acquiring a L2/FL, i.e., what kinds of learners they are and how they learn, b) helping them develop their cognitive and academic language proficiency skills, and c) helping them develop their digital competence.
\end{abstract}

Keywords: identity texts, multimodality, cognitive and academic language proficiency skills (CALPS), teaching for linguistic transfer, EFL. inred@upvnet.es.

\footnotetext{
Resumen

El presente proyecto de investigación-acción en curso se ocupa de la producción y evaluación de "textos de identidad" (Cummins y Early, 2011) en estudiantes de inglés de una asignatura específica dentro de la especialidad de Maestro de Inglés en Educación Primaria de la Facultat de Magisteri de la Universitat de València. Este proyecto es parte de un proyecto de innovación educativa, cuyo principal objetivo es promover el uso de textos de identidad como estrategia del enfoque de "enseñanza para la transferencia lingüistica” (Cummins, 2005b). Los textos de identidad
}

\footnotetext{
1 Este trabajo se enmarca dentro del proyecto de innovación educativa (ref. UV-SFPIE_RMD15-314975).
} 
promueven la transferencia cognitiva y académica desde la lengua primera (L1) a la lengua segunda o extranjera (L2/LE), y ofrecen a los alumnos una oportunidad para explorar sus identidades a través de textos escritos, orales, visuales, musicales y teatrales o una combinación de todos ellos en un todo multimodal (videos, historias digitales, etc.). En este proyecto, los estudiantes exploran sus identidades como aprendices de inglés como lengua extranjera (ILE) con el objetivo de a) concienciarles acerca de quiénes son como tal, por ejemplo, qué tipo de aprendices son y cómo aprenden; b) contribuir al desarrollo de sus habilidades cognitivas y académicas de competencia lingüística; y c) ayudarles a desarrollar su competencia digital.

Palabras clave: textos de identidad, multimodalidad, habilidades cognitivas y académicas de competencia lingüística, enseñanza para la transferencia lingüistica, ILE.

\section{Introducción}

El presente proyecto de investigación-acción es un proyecto en curso que se centra en la producción y la evaluación de textos de identidad por parte de estudiantes universitarios de inglés como lengua extranjera (ILE) en el contexto de la asignatura Didáctica de la Lengua extranjera I (inglés), la cual forma parte de la especialidad de Maestro de Inglés en Educación Primaria de la Facultat de Magisteri de la Universitat de València.

Este proyecto es parte de un proyecto de innovación educativa concedido por el Vicerrectorado de Políticas de Formación y Calidad Educativa de la Universitat de València, cuyo principal objetivo es promover el uso de textos de identidad para ayudar a los estudiantes a transferir su conocimiento lingüístico a través de las lenguas que saben o que dominan, de modo que se desarrollen sus habilidades cognitivas y académicas multilingües.

Los textos de identidad abordan tanto la afirmación de la identidad como el desarrollo de la alfabetización. La investigación ha probado que ambos aspectos son igualmente importantes para el éxito académico de los estudiantes. Se añade a ello, el hecho de que los trabajos de identidad multimodal han demostrado ser altamente eficaces para el desarrollo de las habilidades académicas multimodales y multilingües de los alumnos (Cummins et al., 2015). Por tanto, los textos de identidad constituyen una herramienta útil para el desarrollo de las llamadas habilidades cognitivas y de dominio del lenguaje académico en los alumnos.

\section{Objetivos}

El objetivo principal de este proyecto es suscitar el empleo de textos de identidad en la enseñanza-aprendizaje de lenguas en general, y de lenguas extranjeras en particular, con el

(cc) BY-NC-ND 2016, Universitat Politècnica de València 
fin de promover una pedagogía que abogue por la transferencia interlingüística (Cummins, 2005b). Así pues, en concreto, este proyecto pretende concienciar a los futuros maestros de inglés en Educación Primaria acerca de quiénes son como aprendices de inglés como lengua extranjera (ILE), teniendo en cuenta, por un lado, qué tipo de aprendices piensan que son de acuerdo con las diferencias individuales o los conocidos "factores del aprendiz" establecidos en el campo de estudio de adquisición de segundas lenguas (Ellis, 1994; Skehan, 1998)²; y por otro lado, cómo aprenden la lengua extrajera o qué estrategias de aprendizaje han utilizado o utilizan para ello (Oxford, 1990). Con todo, este proyecto intenta contribuir modestamente al desarrollo de las habilidades cognitivas y académicas de competencia lingüística de estos estudiantes, al tiempo que pretende ayudarles a desarrollar su competencia digital, la cual constituye una competencia crucial en la actualidad tanto en la vida diaria como en el ámbito educativo.

\section{Enfoque Teórico}

\subsection{Textos de identidad}

Según establecen Cummins y Early (2011: 3), los textos de identidad son textos que constituyen el producto del trabajo creativo realizado por los estudiantes en el contexto del aula y en el espacio pedagógico orquestado por el profesor para tal fin. En dichos textos los estudiantes envisten sus identidades, y estos pueden adoptar distintas formas combinables en un todo multimodal. Dichos textos constituyen un vehículo para la afirmación de la autoimagen del estudiante, lo cual contribuye a su progreso en el aprendizaje y dominio de la lengua:

"Identity texts [...] can be written, spoken, signed, visual, musical, dramatic, or combinations in multimodal form. The identity text then holds a mirror up to students in which their identities are reflected back in a positive light. When students share identity texts with multiple audiences (peers, teachers, [...] etc.) they are likely to receive positive feedback and affirmation of self in interaction with these audiences. Although not always an essential component, technology acts as an amplifier to enhance the process of identity text production and dissemination". [Los textos de identidad [...] pueden ser escritos, hablados, producidos en lenguaje de signos, visuales, musicales, teatrales o una combinación de todo ello que adopte forma multimodal. El texto de identidad muestra entonces un espejo a los estudiantes que les devuelve sus identidades reflejadas en una luz positiva. Cuando los estudiantes comparten textos de identidad con múltiples receptores (compañeros, profesores, [...] etc.), suelen recibir retroalimentación positiva y se autoafirman en la interacción con estos. Aunque no siempre es un componente esencial, la tecnología amplifica el proceso de la producción del texto de identidad y su diseminación].

Los textos de identidad pueden adoptar forma de textos bilingües o multilingües, y pueden ser creados de forma conjunta por los estudiantes en grupos, y/o los padres y los profesores.

${ }^{2}$ Para una revisión, vid. Ehrman et al. (2003).

(cc) EY-NC-ND 2016, Universitat Politècnica de València

Congreso In-Red (2016) 
En nuestro caso, los textos de identidad de nuestros estudiantes fueron creados individualmente.

Los textos de identidad fueron concebidos originalmente para ayudar a los estudiantes de inglés de grupos sociales marginados (por ejemplo, inmigrantes) en el aprendizaje del idioma en contexto escolar, es decir, fueron concebidos para contribuir a la escolarización de dichos alumnos en L1 inglés. En este proyecto, sin embargo, pensamos que también pueden utilizarse con otros estudiantes de inglés tales como los aprendices de ILE. Los textos de identidad incorporan la escritura creativa y la narración digital, que actúan como un vehículo mediante el cual los alumnos pueden rechazar estereotipos negativos de sí mismos o de otros, y construir al mismo tiempo una identidad de sujeto competente y eficaz que fomente la participación y el desarrollo académico de los mismos.

En la enseñanza y el aprendizaje de lenguas, el concepto de identidad ha sido definido como la relación que el aprendiz entiende que tiene, mantiene e imagina con el mundo, la construcción de la misma a través del tiempo y del espacio, y la proyección de esta en el futuro (Norton Pierce, 1995; Norton 2000, 2013). La identidad de un individuo emerge pues en las relaciones que este mantiene con otros, y en concreto, en las prácticas comunicativas que tiene con los mismos. Por tanto, es un concepto necesariamente social y discursivo. Además, no constituye un todo unitario, sino más bien, un constructo fragmentado, a veces, contradictorio, multidimensional, y dinámico.

\subsection{Enseñanza para la transferencia interlingüística}

Desde un punto de vista pedagógico, los textos de identidad son una estrategia fundamental del modelo de "enseñanza para la transferencia lingüística" propuesto por Cummins (2005a). Este modelo se basa en la conocida "hipótesis de la interdependencia lingüística" (Cummins 1979, 1983, 2005a), que establece que cada lengua contiene características superficiales; sin embargo, a estas manifestaciones superficiales de las lenguas subyacen competencias que son comunes a todas y que, por tanto, son transferibles. Estas competencias subyacentes implican tareas cognitivamente exigentes, tales como la alfabetización, el aprendizaje de contenidos, el pensamiento abstracto y la resolución de problemas, que requieren un lenguaje complejo o el dominio del lenguaje académico. Esta hipótesis es parte del conocido "modelo iceberg de la interdependencia lingüística", que ha sido generalmente empleado en estudios sobre el bilingüismo y el multilingüismo.

Dichas competencias subyacentes comunes también se conocen como CALP (cognitive academic language proficiency) o competencia cognitiva y académica o de dominio del lenguaje académico. Estas competencias son específicas del contexto escolar, y por tanto, se definen como "the extent to which an individual has access to and command of the oral and written academic registers of schooling" [el grado en el que una persona tiene aceso a y dominio de los registros académicos orales y escritos de la escuela] (Cummins, 2000: 67). Dichas competencias se oponen a lo que Cummins llamó BICS (basic interpersonal communication skills), a saber, habilidades básicas de comunicación interpersonal, las cuales podrían equipararse a las que utilizan los niños en situaciones comunicativas diarias.

(cc) EY-NC-ND 2016, Universitat Politècnica de València

Congreso IN-RED (2016) 
Al igual que estas competencias básicas, las habilidades cognitivas y académicas de competencia lingüística se desarrollan a través de la interacción social desde el nacimiento; sin embargo, se diferencian de las primeras después de las etapas iniciales de la escolarización para reflejar principalmente la lengua que los niños adquieren en la escuela, y que necesitan utilizar con eficacia para poder progresar con éxito en el contexto escolar (Cummins, 2008).

\section{Desarrollo de la innovación}

En este proyecto, se animó a los estudiantes a explorar sus identidades como estudiantes de ILE a través de una tarea individual para el curso Didáctica de la Lengua extranjera I ( inglés). La tarea consistía en crear un texto multimodal de identidad con las siguientes características en cuanto a contenido:

- El texto necesariamente tenía que centrarse en la descripción, bien de una etapa específica del proceso de aprendizaje lingüístico del estudiante como estudiante de ILE, bien de su experiencia de vida como tal hasta la fecha, bien de una anécdota interesante en su proceso de aprendizaje de la lengua.

- El texto de identidad también debía incluir una pregunta dramática en la narración, que guiara la historia o que se respondiera a lo largo de la misma del mismo modo que en la narración digital (Gregori-Signes, 2008, 2014; Robin, 2006).

- Además, el texto de identidad tenía necesariamente que describir a su autor/a a la luz de las diferencias individuales o factores que afectan a la adquisición de la L2/LE, los cuales se comentaron en clase; por ejemplo, la edad, la inteligencia, en concreto, las inteligencias múltiples, la aptitud, la personalidad (centrándose en la ansiedad), la motivación y las creencias.

- Los estudiantes también debían describirse a sí mismos de acuerdo con sus estilos y estrategias de aprendizaje. Por tanto, se esperaba que hablaran en algún momento de sus textos de identidad sobre sus estilos de aprendizaje perceptuales, es decir, si se consideran aprendices visuales, auditivos o kinestésicos, o si lo fueron en algún momento y esto ha cambiado con el tiempo. Además, debían hablar de sus estilos de aprendizaje cognitivo en términos de si se consideran aprendices concretos o abstractos, y por qué, si son aprendices que dependen del contexto o no para su aprendizaje lingüístico, si son estudiantes reflexivos o impulsivos, etc. Además, también debían incluir información sobre sus estrategias de aprendizaje.

En cuanto a forma, los textos de identidad de los alumnos debían adoptar un formato digital multimodal, por ejemplo, a través del uso del video con programas de edición de video tales como (Windows MovieMaker o Audacity, entre otros), la narración digital con programas como Photo Story 3, o el programa de Youtube Powtoon, el cual permite usar personajes animados, insertar gráficos, videos, fotos, etc.

(cc) EY-NC-ND 2016, Universitat Politècnica de València

Congreso In-Red (2016) 
Los textos de identidad de los estudiantes no debían exceder los 7 minutos de duración, y a pesar de que no se produjeron de forma conjunta, es decir, cada estudiante produjo su propio texto de identidad, se estableció que la evaluación de los textos sería realizada por los propios estudiantes. Para ello, se generó una rúbrica de acuerdo con las sugerencias de Gregori-Signes (2014) para la evaluación de historias digitales, y los elementos que contienen dichas historias identificados por Robin (2006) a través del Centro de narración Digital de la Universidad de California (Center for Digital Storytelling, University of California) (vid. Figura 1).

La rúbrica se adaptó a la tarea en cuestión del siguiente modo: los primeros dos ítems, a saber, "Contenido de la historia (propósito)" y "Descripción general" están relacionados directamente con la esencia de los textos de identidad, ya que en el primer caso el contenido de la historia y su propósito es la auto-descripción como aprendiz de ILE, la cual ha de mantenerse a lo largo de toda la narración, y en el segundo caso, dicha auto-descripción ha de reflejar la voz e involucración personal del autor alejada de ideas estereotipadas. Los ítems $6,7,8$, y 9 son también específicos a la tarea en cuestión, puesto que tratan las diferencias individuales o estilos y estrategias de aprendizaje, que mencionábamos anteriormente.

Los estudiantes evaluaron los textos de identidad de sus compañeros de forma anónima, de tal modo que cada alumno evaluó solamente un texto. Para tal fin, fueron emparejados de forma que se trató de evitar el sesgo tanto como fuera posible en sus evaluaciones. Por ejemplo, los estudiantes que por lo general se sientan juntos porque tienen una relación más estrecha no fueron emparejados para la evaluación.

Con respecto a los procedimientos que seguimos para implementar la producción y evaluación de los textos multimodales de identidad de nuestros estudiantes, se creó una carpeta en Google Drive, para que estos pudieran compartir sus textos, y descargar el texto que a cada uno de ellos se le había asignado para su evaluación. La rúbrica de evaluación se proporcionó a posteriori de la entrega de los textos, que podían descargarse para evaluación en un plazo de tiempo determinado. Una vez descargados todos, los estudiantes dispusieron de la rúbrica se procedió a la eliminación de la carpeta compartida para evitar posibles modificaciones de los textos de identidad en vista de la rúbrica de evaluación. Los alumnos entregaron en mano sus evaluaciones. 


\begin{tabular}{|c|c|c|c|c|}
\hline Category & 4 Points & 3 Points & 2 Points & 1 Point \\
\hline $\begin{array}{l}\text { 1. Content of Story } \\
\text { (Purpose) }\end{array}$ & $\begin{array}{l}\text { The purpose of the story, } \\
\text { i.e., self-depiction of oneself } \\
\text { as an EFL learner, is } \\
\text { maintained throughout. }\end{array}$ & $\begin{array}{l}\text { The purpose of the story, i.e., } \\
\text { self-depiction of oneself as an } \\
\text { EFL learner, is maintained most } \\
\text { of the time. }\end{array}$ & $\begin{array}{l}\text { There are a few lapses in focus, } \\
\text { but the purpose of the story, } \\
\text { i.e., self-depiction of oneself as } \\
\text { an EFL learner, is fairly clear. }\end{array}$ & $\begin{array}{l}\text { It is difficult to figure out } \\
\text { that the purpose of the story } \\
\text { is one's self-depiction as an } \\
\text { EFL learner. }\end{array}$ \\
\hline 2. Overall Depiction & $\begin{array}{l}\text { The depiction of oneself as } \\
\text { an EFL learner reflects the } \\
\text { author's personal } \\
\text { involvement and gets away } \\
\text { from general ideas that } \\
\text { invoke stereotypical notions }\end{array}$ & $\begin{array}{l}\text { The depiction of oneself as an } \\
\text { EFL learner reflects the author's } \\
\text { personal involvement, but } \\
\text { sometimes reflects general ideas } \\
\text { that invoke stereotypical notions }\end{array}$ & $\begin{array}{l}\text { The depiction of oneself as an } \\
\text { EFL learner reflects the } \\
\text { author's personal involvement, } \\
\text { but many times reflects } \\
\text { general ideas that invoke } \\
\text { stereotypical notions }\end{array}$ & $\begin{array}{l}\text { The depiction of oneself as } \\
\text { an EFL learner is based on } \\
\text { general ideas that invoke } \\
\text { stereotypical notions }\end{array}$ \\
\hline 3. Structure of Story & $\begin{array}{l}\text { The story is coherent in } \\
\text { terms of structure }\end{array}$ & $\begin{array}{l}\text { The story is coherent for the } \\
\text { most part in terms of structure }\end{array}$ & $\begin{array}{l}\text { The story is fairly coherent in } \\
\text { terms of structure }\end{array}$ & $\begin{array}{l}\text { The story is difficult to } \\
\text { follow, since it lacks a clear } \\
\text { structure }\end{array}$ \\
\hline $\begin{array}{l}\text { 4. Economy of Story } \\
\text { \& Detail }\end{array}$ & $\begin{array}{l}\text { The story is told with exactly } \\
\text { the right amount of detail } \\
\text { throughout. It does not seem } \\
\text { too short nor does it seem } \\
\text { too long }\end{array}$ & $\begin{array}{l}\text { The story composition is typically } \\
\text { good, though it seems to drag } \\
\text { somewhat OR need slightly more } \\
\text { detail in one or two sections. }\end{array}$ & $\begin{array}{l}\text { The story seems to need more } \\
\text { editing. It is noticeably too long } \\
\text { or too short in more than one } \\
\text { section. }\end{array}$ & $\begin{array}{l}\text { The story needs extensive } \\
\text { editing. It is too long or too } \\
\text { short to be interesting. }\end{array}$ \\
\hline $\begin{array}{l}\text { 5. Grammar and } \\
\text { Language Usage }\end{array}$ & $\begin{array}{l}\text { Grammar and usage are } \\
\text { correct and contributed to } \\
\text { clarity, style and character } \\
\text { development. }\end{array}$ & $\begin{array}{l}\text { Grammar and usage are typically } \\
\text { correct and errors do not detract } \\
\text { from the story. }\end{array}$ & $\begin{array}{l}\text { Grammar and usage are } \\
\text { typically correct but errors } \\
\text { detract from story. }\end{array}$ & $\begin{array}{l}\text { Repeated errors in grammar } \\
\text { and usage distract greatly } \\
\text { from the story. }\end{array}$ \\
\hline $\begin{array}{l}\text { 6. Learner } \\
\text { Characteristics } \\
\text { (individual } \\
\text { differences) } \\
\end{array}$ & $\begin{array}{l}\text { At least } 5 \text { of the individual } \\
\text { differences or learner factors } \\
\text { discussed in class are } \\
\text { included in the description }\end{array}$ & $\begin{array}{l}\text { At least } 3 \text { of the individual } \\
\text { differences or learner factors } \\
\text { discussed in class are included in } \\
\text { the description }\end{array}$ & $\begin{array}{l}\text { At least } 2 \text { of the individual } \\
\text { differences or learner factors } \\
\text { discussed in class are included } \\
\text { in the description }\end{array}$ & $\begin{array}{l}\text { None of the individual } \\
\text { differences or learner factors } \\
\text { discussed in class are } \\
\text { included in the description }\end{array}$ \\
\hline $\begin{array}{l}\text { 7. Learner } \\
\text { Characteristics } \\
\text { (perceptual } \\
\text { learning styles) }\end{array}$ & $\begin{array}{l}\text { Perceptual learning styles } \\
\text { have been considered in the } \\
\text { description }\end{array}$ & $\begin{array}{l}\text { Perceptual learning styles have } \\
\text { been considered in the } \\
\text { description for the most part }\end{array}$ & $\begin{array}{l}\text { Perceptual learning styles have } \\
\text { been rarely considered in the } \\
\text { description }\end{array}$ & $\begin{array}{l}\text { Perceptual learning styles } \\
\text { have not been considered in } \\
\text { the description }\end{array}$ \\
\hline $\begin{array}{l}\text { 8. Learner } \\
\text { Characteristics } \\
\text { (cognitive learning } \\
\text { styles) }\end{array}$ & $\begin{array}{l}\text { At least } 5 \text { of the different } \\
\text { cognitive learning styles } \\
\text { discussed in class are } \\
\text { included in the description }\end{array}$ & $\begin{array}{l}\text { At least } 3 \text { of the different } \\
\text { cognitive learning styles } \\
\text { discussed in class are included in } \\
\text { the description }\end{array}$ & $\begin{array}{l}\text { At least } 2 \text { of the different } \\
\text { cognitive learning styles } \\
\text { discussed in class are included } \\
\text { in the description }\end{array}$ & $\begin{array}{l}\text { Cognitive learning styles } \\
\text { have not been included in } \\
\text { the description }\end{array}$ \\
\hline 9. Leaner Strategies & $\begin{array}{l}\text { Learner strategies have been } \\
\text { considered in the description }\end{array}$ & $\begin{array}{l}\text { Learner strategies have been } \\
\text { considered in the description for } \\
\text { the most part }\end{array}$ & $\begin{array}{l}\text { Learner strategies have been } \\
\text { rarely considered in the } \\
\text { description }\end{array}$ & $\begin{array}{l}\text { Learner strategies have not } \\
\text { been considered in the } \\
\text { description }\end{array}$ \\
\hline $\begin{array}{l}\text { 10. Dramatic } \\
\text { Question }\end{array}$ & $\begin{array}{l}\text { A meaningful dramatic } \\
\text { question is asked and } \\
\text { answered within the context } \\
\text { of the story. }\end{array}$ & $\begin{array}{l}\text { A dramatic question is asked but } \\
\text { not clearly answered within the } \\
\text { context of the story. }\end{array}$ & $\begin{array}{l}\text { A dramatic question is hinted } \\
\text { at but not clearly established } \\
\text { within the context of the story. }\end{array}$ & $\begin{array}{l}\text { Little or no attempt is made } \\
\text { to pose a dramatic question } \\
\text { or answer it. }\end{array}$ \\
\hline $\begin{array}{l}\text { 11. Choice of } \\
\text { Content }\end{array}$ & $\begin{array}{l}\text { Contents create a distinct } \\
\text { atmosphere or tone that } \\
\text { matches different parts of } \\
\text { the story. The images may } \\
\text { communicate symbolism } \\
\text { and/or metaphors. }\end{array}$ & $\begin{array}{l}\text { Contents create an atmosphere } \\
\text { or tone that matches some parts } \\
\text { of the story. The images may } \\
\text { communicate symbolism and/or } \\
\text { metaphors. }\end{array}$ & $\begin{array}{l}\text { An attempt was made to use } \\
\text { contents to create an } \\
\text { atmosphere/tone but it } \\
\text { needed more work. Image } \\
\text { choice is logical. }\end{array}$ & $\begin{array}{l}\text { Little or no attempt to use } \\
\text { contents to create an } \\
\text { appropriate } \\
\text { atmosphere/tone. }\end{array}$ \\
\hline $\begin{array}{l}\text { 12. Choice of } \\
\text { Images }\end{array}$ & $\begin{array}{l}\text { The images selected for the } \\
\text { story fully match the } \\
\text { different parts of the story in } \\
\text { an original and creative way. }\end{array}$ & $\begin{array}{l}\text { The images selected for the story } \\
\text { match some parts of the story in } \\
\text { an original and creative way. }\end{array}$ & $\begin{array}{l}\text { The images selected for the } \\
\text { story hardly match the } \\
\text { different parts of the story, and } \\
\text { image choice is logical. }\end{array}$ & $\begin{array}{l}\text { Little or no attempt has been } \\
\text { made to use images that } \\
\text { match the different parts of } \\
\text { the story, so that image } \\
\text { choice needs a lot of work. }\end{array}$ \\
\hline 13. Clarity of Voice & $\begin{array}{l}\text { Voice quality is clear and } \\
\text { consistently audible } \\
\text { throughout the story. }\end{array}$ & $\begin{array}{l}\text { Voice quality is clear and } \\
\text { consistently audible throughout } \\
\text { the majority (85-95\%) of the } \\
\text { story. }\end{array}$ & $\begin{array}{l}\text { Voice quality is clear and } \\
\text { consistently audible through } \\
\text { some }(70-84 \%) \text { of the story. }\end{array}$ & $\begin{array}{l}\text { Voice quality needs more } \\
\text { attention. }\end{array}$ \\
\hline $\begin{array}{l}\text { 14. Pacing of } \\
\text { Narrative }\end{array}$ & $\begin{array}{l}\text { The pace (rhythm and voice } \\
\text { punctuation) fits the story } \\
\text { line and helps the audience } \\
\text { really "get into" the story. }\end{array}$ & $\begin{array}{l}\text { The narrator occasionally speaks } \\
\text { too fast or too slowly for the } \\
\text { story line. The pacing (rhythm } \\
\text { and voice punctuation) is } \\
\text { relatively engaging for the } \\
\text { audience. }\end{array}$ & $\begin{array}{l}\text { The narrator tries to use pacing } \\
\text { (rhythm and voice } \\
\text { punctuation), but it is often } \\
\text { noticeable that the pacing does } \\
\text { not fit the story line. As a } \\
\text { result, the audience is not } \\
\text { consistently engaged. }\end{array}$ & $\begin{array}{l}\text { No attempt has been made } \\
\text { to match the pace of the } \\
\text { storytelling to the story line } \\
\text { or the audience. }\end{array}$ \\
\hline $\begin{array}{l}\text { 15. Meaningful } \\
\text { Audio Soundtrack }\end{array}$ & $\begin{array}{l}\text { Music stirs a rich emotional } \\
\text { response that matches the } \\
\text { story line well. Images are } \\
\text { coordinated with the music. }\end{array}$ & $\begin{array}{l}\text { Music stirs a rich emotional } \\
\text { response that somewhat } \\
\text { matches the story line. Images } \\
\text { are mostly coordinated with the } \\
\text { music. }\end{array}$ & $\begin{array}{l}\text { Music is ok, and not } \\
\text { distracting, but it does not add } \\
\text { much to the story. Images are } \\
\text { not coordinated with the } \\
\text { music. }\end{array}$ & $\begin{array}{l}\text { Music is distracting, } \\
\text { inappropriate, OR was not } \\
\text { used. }\end{array}$ \\
\hline
\end{tabular}

Fig. 1 Rúbrica de evaluación

\section{Análisis y Resultados}

En términos del análisis, los textos de nuestros alumnos se analizaron desde dos perspectivas: la afirmación de la identidad y el desarrollo de la alfabetización. Así pues, en cuanto a la identidad que presentaron los estudiantes a través de sus textos multimodales, el

(cc) EY-NC-ND 2016, Universitat Politècnica de València

Congreso In-Red (2016) 
análisis se basó en una "perspectiva posicionante" (Davies y Harré, 1990) por medio de la cual se examinaron los textos desde una posición "interactiva" - los enunciados del hablante posicionan al interlocutor a través de la toma de turnos-, y una posición "reflexiva"-el mismo hablante actúa para posicionarse a sí mismo.

En cuanto a la primera, el análisis reveló que nuestros alumnos de ILE establecían un intercambio comunicativo con el espectador de manera indirecta mediante títulos que asignaban a sus relatos (por ejemplo, "My experience as a language learner", "Me as a language learner", etc.); y de manera directa mediante conversaciones ficticias que entablaban con él de forma oral y parcialmente de forma escrita con algunos enunciados que aparecían en algunas secuencias de sus videos. En algunos casos, todo el relato consistía en una conversación continuada con el espectador el cual en ocasiones constituía un ente genérico, y en otras se concretaba con los compañeros de clase. El siguiente ejemplo ilustra estos resultados.

Ejemplo (1)

Hi, I'm JP and I'm making this video to answer a question, and this is if it's possible to learn English without, without, eeeh, without teachers, without proper lessons, without a typical environment of learning. And I'm going to start asking this question from the beginning...that I was, eeeehm, seven or eight years-old when I had my first contact with eeh, English. And I think that it was, eeeehm, I don't know why, my sisters bought me for Christmas a CD of Linkin Park (se rie) [...] so I think the question was answered and thank you for your time.

En este el autor y narrador de la historia aparece sentado frente a la cámara y habla directamente con el que está al otro lado de ella como si se tratara de un presentador de televisión. El extracto pertenece al inicio y al final del relato, en el cual el narrador se presenta al espectador y describe el eje vertebrador de su historia, a saber, la cuestión de si es posible aprender inglés fuera del típico contexto de aprendizaje formal que caracteriza a la enseñanza-aprendizaje de una lengua extranjera, y finaliza esta historia dando una respuesta a dicha cuestión y agradeciendo al espectador el tiempo que le ha dedicado.

Respecto a la posición reflexiva, se observó que esta giraba principalmente en torno a la identidad de los alumnos como aprendices de inglés, con la cual se relacionaban posiciones definidas por contextos formales y naturales de enseñanza tales como "aprendiz de inglés en el contexto escolar", "aprendiz de inglés en actividades extraescolares", "aprendiz de inglés en clases particulares", "aprendiz de inglés en academia de idiomas", "estudiante Erasmus", y "estudiante internacional". En el caso de la posición de "aprendiz de inglés en el contexto escolar", la mayoría de los estudiantes describían esta posición realizando un recorrido histórico desde la etapa de la Educación Primaria hasta la etapa de la Educación Secundaria o la universitaria, y manifestaban actitudes negativas hacia la misma, mostrándola como una "identidad silenciadora" desde la que no tenían oportunidad de expresarse libremente, especialmente de manera oral, y ser escuchados (Norton, 2010; Norton y Toohey, 2011). Además, relacionaban dicha posición a "pedagogías de transmisión" (cf. Cummins, 2006) que niegan al aprendiz de lenguas el acceso a un uso real

(cc) EY-NC-ND 2016, Universitat Politècnica de València

Congreso IN-RED (2016) 
de estas, y la posibilidad de atribuir sentido a su proceso de aprendizaje y verlo como un aprendizaje significativo. La posición de "aprendiz de inglés en el contexto escolar" también se relacionaba por lo general con otras que describían a tipos de aprendiz poco eficaces, por ejemplo, "aprendiz de inglés de oído", incapaz de escribir correctamente, y "aprendiz de inglés como oyente", incapaz de utilizar la lengua de manera oral y comunicarse con otros. Los alumnos se atribuían a sí mismos dichas posiciones como parte de su identidad en algún momento de su aprendizaje lingüístico, y mostraban su rechazo hacia las mismas. Ello no solo corrobora la idea de que estas posiciones constituyen posiciones silenciadoras, sino también el hecho de que la identidad es un constructo fluido y cambiante en el tiempo y en el espacio.

En relación con las posiciones de "aprendiz de inglés en actividades extraescolares", "aprendiz de inglés en clases particulares" y "aprendiz de inglés en academia de idiomas", estas constituían identidades de "tránsito", es decir, posiciones que permiten alcanzar identidades imaginadas (imagined identities) al aprendiz o confirmar identidades reales que este desea y valora (Norton y Toohey, 2011). Estas identidades imaginadas constituyen "identidades de competencia" o de éxito académico (Manyak, 2004), y en los textos objeto de estudio incluían las posiciones de "aprendiz de inglés en contexto de inmersión lingüística", "aprendiz de inglés con competencia oral y escrita casi nativa", "hablante de inglés en la comunicación oral", "bilingüe simultáneo/familiar", "ciudadano intercultural" y "maestro/a de inglés en Educación Primaria".

Las identidades de tránsito anteriormente mencionadas ("aprendiz de inglés en actividades extraescolares", "aprendiz de inglés en clases particulares" y "aprendiz de inglés en academia de idiomas") eran descritas tanto de manera positiva como de manera negativa, en ocasiones por el mismo alumno, lo cual muestra la naturaleza contradictoria de la identidad señalada por algunos autores (Darvin, 2016). El siguiente ejemplo ilustra como la posición de "aprendiz de inglés en actividades extraescolares" ayudó a la alumna a sentirse más eficaz como aprendiz de inglés (I learnt a lot of English gramar) a la vez que contribuía a disminuir su motivación por seguir aprendiendo y promovía en ella sentimientos negativos hacia su propio proceso de aprendizaje (I was unmotivated because I was doing fill in the gaps exercises all the time).

Ejemplo (2)

...I went to private lessons for seven years. There I learnt a lot of English grammar (secuencia con libros de gramática). In those lessons I was unmotivated because I was doing fill in the gaps exercises all the time.

Respecto a la alfabetización, los textos mostraron el conocimiento de los alumnos sobre determinados recursos y sus usos en la lengua extranjera en un contexto tecnológico. En particular, los alumnos de ILE mostraron su alfabetización digital a través del empleo de un estilo discursivo afectivo marcado por un alto grado de intensificación, el cual se observó en el uso de palabras o letras en mayúscula, el empleo de los signos de puntuación no normativo (por ejemplo, puntos suspensivos o signos de exclamación e interrogación repetidos: "Why did I decide to learn English??!!"), frecuencia excesiva de elementos 
intensificadores (really, very, etc.), cuantificadores extremos (all), repeticiones diversas, y un registro coloquial más común del habla que de la escritura. Así pues, el empleo de estos recursos en sus textos de identidad multimodales no solo muestra el conocimiento que poseen los alumnos sobre los mismos y su uso en la comunicación digital, sino también, un conocimiento general de cómo ha de ser este tipo de comunicación en un tipo de texto concreto como el texto de identidad multimodal, el cual transfieren de su L1 a la lengua extranjera. Dicho conocimiento general se observó, entre otras cosas, en el uso de cierres discursivos como "The end" (Fin), típico de las películas mudas y de los dibujos animados de los años 80-90 de origen anglófono, en ocasiones, seguido del título del relato, y el nombre de su autor principalmente, siguiendo la estructura de estos géneros televisivos, o de expresiones como "thank you for your attention"; el empleo de imágenes en forma de fotos y vídeos personales para mostrar claramente al espectador su "yo"; el uso de la narración autobiográfica; etc.

Por tanto, los textos de identidad multimodales facilitan la transferencia de conocimiento lingüístico y discursivo entre lenguas, y constituyen una oportunidad para que el alumno de ILE amplíe el repertorio de recursos simbólicos y materiales que posee en la lengua meta y reflexiones sobre su identidad como aprendiz de inglés. Todo ello facilita la construcción y representación de identidades de competencia en los alumnos, que de este modo se sienten más capaces de expresarse en la lengua meta y se motivan para seguir aprendiéndola. El siguiente ejemplo muestra una de estas identidades en una alumna:

\section{Ejemplo 3}

I've realised that without English language I couldn't have enjoyed that experiences. So

I'm very proud to have studied it during these last years.

La autora de este relato echa la vista atrás hacia los años que ha pasado aprendiendo inglés, y se siente orgullosa de dicho recorrido, enfatizando experiencias positivas que ha vivido gracias al aprendizaje de esta lengua como la de haber sido estudiante internacional en su caso.

\section{Conclusiones}

Esta comunicación presenta un proyecto de investigación-acción en el aula que es parte de un proyecto mayor de innovación educativa, cuyo objetivo principal es el empleo de textos de identidad para promover la transferencia de las habilidades cognitivas y de dominio del lenguaje académico en futuros maestros de inglés en Educación Primaria. La transferencia de dichas habilidades es fundamental en el contexto educativo plurilingüe que caracteriza a la sociedad en la actualidad.

Así pues, este proyecto de investigación-acción pretende, por una parte, ayudar a los estudiantes a mejorar su dominio del inglés potenciando el desarrollo de sus habilidades cognitivas y académicas mediante la transferencia interlingüística desde su L1 a su L2 o LE; y por otra parte, intenta ofrecer a los estudiantes la oportunidad de explorar su "yo" a 
través del uso de textos escritos, visuales, musicales, orales y teatrales o una combinación de todos ellos en un conjunto multimodal (a saber, videos, relatos digitales, etc.).

\section{Referencias}

Cummins, J. (1979). "Linguistic interdependence and the educational development of bilingual children". Review of Educational Research, 49, 221-251.

Cummins, J. (1983). "Interdependencia lingüística y desarrollo educativo de los niños bilingües", Infancia y Aprendizaje, 21, 37-61.

Cummins, J. (2000). Language, Power and Pedagogy: Bilingual Children in the Crossfire. Clevedon, England: Multilingual Matters.

Cummins, J. (2005a). "La hipótesis de interdependencia 25 años después" [The interdependence hypothesis 25 years later: Current research and implications for bilingual education]. En LASAgabaster, D. y Sierra, J. (eds.), Multilingüismo y multiculturalismo en la escuela. Barcelona: ICE-HORSORI y Universitat de Barcelona, 113-132.

Cummins, J. (2005b). "Teaching for cross-language transfer in dual language education: possibilities and pitfalls". http://www.achievementseminars.com/seminar_series_2005_2006/readings/tesol.turkey. pdf. [Consulta: 24 de marzo de 2016]

Cummins, J. (2006). "Identity texts: The imaginative construction of self through multiliteracies pedagogy". En O. García, T. Skutnabb-Kambas, y M. Torres Guzman (eds.), Imagining Multilingual Schools: Language in Education and Glocalization. Clevedon: Multilingual Matters, 5168 .

Cummins, J. (2008). "BICS and CALP: Enpirical and theoretical status of the distinction". En Street, B. y Hornberger, N.H. (eds.), Encyclopedia of Language and Education (2nd. edition), Vol. 2: Literacy, 71-83.

Cummins, J. y EARly, M. (2011). Identity Texts: The Collaborative Creation of Power in Multilingual Schools. UK: Trenthan Books.

Cummins, J., Hu, S., Markus, P., y Montero, M.K. (2015). "Indetity texts and academic achievement: connceting the dots in multilingual school settings". TESOL Quarterly, 49, 555-581.

DAVIES, B. y HARRÉ, R. (1990). "Positioning: The discursive production of selves". Journal for the Theory of Social Behaviour, 20(1), 43-63.

Darvin, R. (2016). "Language and identity in the digital age". En PreECE S. (ed.), The Routledge Handbook of Language and Identity. London: Routledge, 523-539.

ElLIS, R. (1994). The Study of Second Language Acquisition. Oxford: Oxford University Press.

EHRMAN, M.E., LEAVER, B.L. y OXFORD, R. (2003). "A brief overview of individual differences in second language learning". System, 31, 313-330.

GrEgori-Signes, C. (2008). "Intergrating the old and the new: Digital Storytelling in the EFL classroom”. GRETA Journal, 16, 43-49.

Gregori-Signes, C. (2014). "Digital storytelling and multimodal literacy in education". Porta Linguarum, 22, 237-250.

2016, Universitat Politècnica de València

Congreso In-Red (2016) 
MANYAK, P. C. (2004). "'What did she say?' Translation in a primary-grade English immersion class". Multicultural Perspectives, 6, 1-218.

Norton, B. (2000). Identity and Language Learning: Gender, Ethnicity and Educational Change. Harlow: Pearson Education.

Norton, B. (2010) "Language and identity". En Hornberger, N. y McKay, S. (eds.), Sociolinguistics and Language Education. Bristol, UK: Multilingual Matters, 349-369.

Norton, B. (2013). Identity and Language Learning: Extending the Conversation (2nd ed.). Bristol, England: Multilingual Matters.

Norton Peirce, B. (1995). "Social identity, investment and language learning". TESOL Quarterly, 29(1), 9-31.

Norton, B. y ToOhey, K. (2011). "Identity, language learning, and social change". Language Teaching 44(4), 412-446.

OxForD, R.L. (1990). Language Learning Strategies: What Every Teacher Should Know. Boston: Heinle \& Heinle.

RoBIN, B. R. (2006). "The educational uses of digital storytelling”. http://digitalliteracyintheclassroo m.pbworks.com/f/Educ-Uses-DS.pdf. [Conculta 22 de marzo de 2016].

SkEHAN, P., (1998). A Cognitive Approach to Language Learning. Oxford: Oxford University Press. 